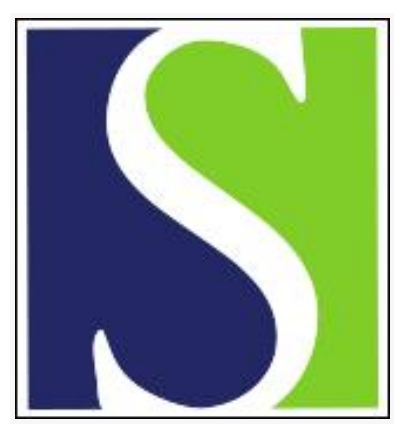

Scand J Work Environ Health 1987;13(1):18-25

https://doi.org/10.5271/sjweh.2085

Issue date: Feb 1987

Mortality and disability among granite workers.

by Koskela RS, Klockars M, Jarvinen E, Kolari PJ, Rossi A

This article in PubMed: www.ncbi.nlm.nih.gov/pubmed/3576141

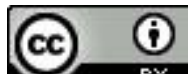




\title{
Mortality and disability among granite workers
}

\author{
by Riitta-Sisko Koskela, MSocSc1, Matti Klockars, MD, Erkki Järvinen, MSc, \\ Pertti J Kolari, MSc, Aija Rossi, MSocSc'
}

\begin{abstract}
KOSKELA R-S, KLOCKARS M, JÄRVINEN E, KOLARI PJ, ROSSI A. Mortality and disability among granite workers. Scand $J$ Work Environ Health 13 (1987) $18-25$. The objective of the present study was to investigate the mortality, disability, and long-term morbidity of granite workers. The study included 1026 workers hired between 1940 and 1971 and followed until the end of 1981 . The total number of deaths was 235 , and the expected number was 229.7 . Excess mortality rates were observed for respiratory diseases (observed/expected $=28 / 13.9$ ). The number of tumor deaths was 46 (expected 44.9). Excess lung cancer mortality was evident at 15 to 35 years of latency; the observed number of lung cancer deaths for the follow-up period of 25 to 29 years was 8 , while 2.1 were expected. Mortality from cardiovascular diseases and violent deaths was slighty less than expected. The results for disability and long-term morbidity showed elevated incidence and prevalence rates for respiratory diseases and rheumatoid arthritis. The observed number of disability pensions due to rheumatoid arthritis in 1981 was 10 observed versus 1.8 expected, and the observed number of patients granted free medication was 19 versus 8.1 expected. The results indicate that granite dust exposure per se may be an etiologic and pathogenetic factor for lung cancer, cancer of the gastrointestinal tract, and some extrapulmonary nonmalignant chronic diseases.
\end{abstract}

Key terms: cohort study, gastrointestinal cancer, immunotoxicology of silica, lung cancer, osteoarthritis, respiratory diseases, rheumatoid arthritis, silicosis.

The relation between exposure to inorganic dusts such as silica and the development of lung disease is well recognized. Most research, both epidemiologic investigations and studies related to the pathophysiology of silica-induced disease, has been concerned with silicosis. Silicosis may be complicated by pulmonary heart disease, bronchitis, emphysema, and spontaneous pneumothorax and segmental middle lobe collapse (27).

Lung cancer occasionally occurs in silicotics, but there is incomplete evidence of a cause-effect relationship between cancer and silicosis or siliceous dusts $(9,12,16,29,35,36)$. Even fewer epidemiologic studies have been done on workers exposed to "pure" silica $(8,33)$. In addition, methodological difficulties have hindered the detection of possible associations between silica exposure and cancer.

Besides tuberculosis and cancer of the lung, several other diseases, such as progressive systemic sclerosis, rheumatoid arthritis, systemic lupus erythematosus, and nephropathy, have also been ascribed to silica exposure $(7,13,30$ and our own unpublished results).

In 1972 the Finnish Institute of Occupational Health carried out a field study on granite workers. The study comprised a health screening program for current workers and a survey of occupational exposures (including dust, vibration, and noise) (1). In addition, disability and mortality were studied in a cohort of gran-

I Institute of Occupational Health, Helsinki, Finland.

Reprint requests to: Ms R-S Koskela, Institute of Occupational Health, Topeliuksenkatu 41 a A, SF-00250 Helsinki, Finland.

18 ite workers hired in 1940-1971 $(17,20)$. This cohort, which was composed of workers with fairly pure quartz dust exposure, has now been followed for at least ten years and investigated for mortality, disability and chronic diseases.

\section{Subjects and methods}

\section{Subjects}

The study cohort comprised 1026 Finnish granite workers employed in quarries and processing yards from three regions (Vehmaa, Viitasaari, and Kuru) in the middle and southwest parts of Finland for at least three months between 1940 and 1971. The workers' ages ranged from 15 to 72 (median 27) years at the time of entry into the cohort. The mean length of exposure to quartz dust was about 12 years.

Each worker's name, date and place of birth, and work history at the companies were collected from the employers' personnel records. The persons were traced through the Population Data Register, and all of them could be traced.

The mortality of the cohort has been followed up three times, until the end of 1972, 1975, and 1981. The annual cohort entries and the proportion of deaths are shown in figure 1 . At the end of the first follow-up period the number of person-years was $13184 ; 119$ deaths were observed. At the end of the second followup period the number of person-years was 15068 , and the number of deaths 148 . By the end of the third follow-up period (1981) 20165 person-years had ac- 
cumulated, and the number of deaths was 235 . (See table 2 in the Results section.)

The causes of death were ascertained from death certificates according to the eighth revision of the International Classification of Diseases (ICD) (26). Even though the calculations of the mortality rates were based on the primary cause of death, the other (secondary) causes were also coded for the study of disease combinations and case analyses. The death certificates were obtained from the Central Statistical Office of Finland and, for those who had emigrated to Sweden, from Swedish Statistics. The disability of the granite workers has been followed up twice, until the end of 1971 and 1981. The causes of disability, coded according to the ICD, were obtained from the Social Insurance Institution. Diseases for which medication was free according to the national sickness insurance law were similarly followed until 30 June 1981 . This information was also obtained from the Social Insurance Institution.

\section{Basis for comparison}

The official statistics on causes of death in 1965 (for mortality from 1940 to 1972), in 1969 (for mortality from 1940 to 1975), and in 1972 (for mortality from 1940 to 1981) were selected for the comparison with the general male population $(37,38,39)$. These years represented the median for the years of deaths during the respective follow-up period. Period-specific mortality results were also calculated according to years since entry (latency periods), in five-year periods. In this analysis, the mortality figures from 1972 were used for the comparison. The median years of all deaths were selected for comparison because in our earlier studies the expected numbers, based on the median year of deaths, correlated well with the calendar periodspecific expected numbers. In addition, we calculated, the median years of cancer deaths and cardiovascular deaths separately, the maximum deviation being three years (1975).

The prevalent numbers (as of 31 December 1981) and incidence rates (from 1969 to 1981) for the disability pensions of the granite workers were compared with the corresponding figures of the male population of working capacity for the same period of time (31). The prevalent numbers of persons granted free medication by the end of 1981 were compared with the corresponding expected numbers for the general male population of Finland (32).

\section{Exposures}

A survey of dust, vibration, and noise exposure and the health, disability, and mortality of the workers in the Finnish granite industry (quarrying, crushing, and block processing) was performed by the Institute of Occupational Health in 1970-1972. Dust was measured in 28 quarries and processing yards and in four crushing plants. Dust concentrations were high in several work phases. The highest concentrations were noted in drilling, the hygienic standard $\left(0.2 \mathrm{mg} / \mathrm{m}^{3}\right)$ for quartz being exceeded, on the average, 10 -fold. The concentration of dust varied with the work phase. In drilling, the total dust concentrations ranged from 12 to $116 \mathrm{mg} / \mathrm{m}^{3}$, and the geometric mean was 39.8 $\mathrm{mg} / \mathrm{m}^{3}$. In the surfacing of blocks with a pneumatic hammer the range was $4-94 \mathrm{mg} / \mathrm{m}^{3}$, and the geometric mean $24.9 \mathrm{mg} / \mathrm{m}^{3}$. In other work phases the range was $0.3-90 \mathrm{mg} / \mathrm{m}^{3}$ and the geometric mean ranged from 1.7 to $28.1 \mathrm{mg} / \mathrm{m}^{3}$. The ranges of the quartz concentrations were $0.3-4.2 \mathrm{mg} / \mathrm{m}^{3}$ (geometric mean $1.47 \mathrm{mg} / \mathrm{m}^{3}$ ), $0.2-4.9 \mathrm{mg} / \mathrm{m}^{3}$ (geometric mean $0.82 \mathrm{mg} / \mathrm{m}^{3}$ ), and $0.02-3.6 \mathrm{mg} / \mathrm{m}^{3}$ (geometric mean $0.12-1.44 \mathrm{mg} / \mathrm{m}^{3}$ ) for drilling, block surfacing and other work phases, respectively (1).

The location of the granite workplaces probably excluded coexposure to carginogens such as radiation, asbestos, or polycyclic aromatic hydrocarbons from organic combustion products (25). Earlier or later occupational exposure to such agents must have also been minor because of the long-term employment in granite work (1). For instance, two-thirds of the granite workers in 1972 were still living in their native parish, and only $7 \%$ of the current granite workers had been employed in other industrial work.

Smoking habits were clarified by questionnaire during the health screening in 1970-1972. The percentage of nonsmokers was 21 , exsmokers 17 , and smokers 62 . The granite workers' smoking habits were thus similar to those of other Finnish groups of active male workers of the same age (3).

\section{Statistical analysis}

In the analysis of mortality, the age-specific observed and expected numbers of deaths and the standardized mortality ratio (SMR) values were computed by cause of death. The cohort was also stratified in five-year periods, according to the length of follow-up, and the mortality rates were calculated for each period separately. The age-specific and cause-specific observed numbers of deaths were tested against the correspond-

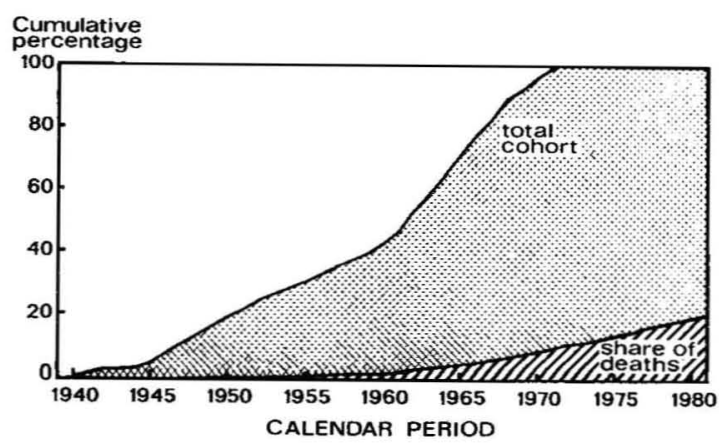

Figure 1. Annual cohort entries and the cumulative incidence $(\%)$ of deaths by calendar period. 
ing expected numbers, based on national figures (SMR), by the Poisson-distribution model (21).

The age-specific and cause-specific prevalent numbers of disability pensions were calculated at the end of the two follow-up periods, as of 31 December 1971 and 31 December 1981. The incidence rates of disability pensions were also calculated for the periods from 1 January 1969 to 31 December 1981 . The expected numbers were computed for the prevalent figures by dividing the observed cases multinomially according to the proportions in the whole population. The Poisson distribution model was used to test the observed number of prevalent disability pensions against the expected number. The incidence densities were tested with the Mantel-Haenszel chi-square test for incidence density data (28).

The use of prescribed free medication was calculated as age-specific and cause-specific prevalences on 30 June 1971 and at the end of 1981. The prevalences were calculated for the most common diseases for which free medication was granted and for diseases which were determined to be excessive in the mortality and/or disability analyses or which could be associated etiologically with these diseases. The expected numbers were calculated in the same manner as those for prevalent figures of disability pensions. The Poisson distribution was used as an approximate method to test the observed number of persons with free medication against the expected number.

\section{Results}

\section{Mortality}

At the end of 1981 the overall mortality among the granite workers was nearly the same as among the total male population of Finland (SMR 102) (table 1). Violent deaths were slightly less frequent among the granite workers than was expected. The violent deaths had taken place mainly during leisure time (ie, traffic accidents and suicides); only two of 28 such deaths were occupational accidents. Cardiovascular deaths were fewer among the granite workers than among the general male population until the age of 65 years. Coronary deaths were also fewer than expected.

The mortality from tumors was nearly the same as that of the male population [SMR 102, $95 \%$ confidence interval (CI) 75-137]. Of the 46 tumors, 22 were lung cancers (expected 17.1). In addition lung cancer was mentioned as the secondary cause of death in two cases of coronary heart disease and in one case of suicide. Mortality from cancer of the digestive organs was 1.6 times the expected value (observed 15, expected 9.7). Nine such cases were cancer of the stomach (expected 6.0), and cancer of the stomach was reported as a secondary cause in one case of coronary death. The other tumors reported as primary $(\mathrm{N}=9)$ or secondary $(\mathrm{N}=2)$ causes were not concentrated in any specific category of cancer diagnosis. A closer analysis of the cancer mortality can be found in another paper (19).

There were 28 deaths from respiratory diseases (SMR 201, $95 \%$ CI 134-291). Of these 10 were silicotic and 18 nonsilicotic (emphysema, chronic bronchitis, bronchial asthma, and pneumonia) pulmonary diseases. Silicosis was thus observed to be the main cause of death for $4.3 \%$ and a secondary cause of death for $2.6 \%$ of all the deceased. Silicosis as the primary cause of death was connected with lung cancer only in one case (early lung cancer as a secondary cause), with other respiratory disease in three cases, and with cardiovascular disease in five cases. Rheu-

Table 1. Mortality from certain causes ${ }^{a}$ in the cohort in an age-specific comparison with the expectd (E) number of deaths calculated on the basis of death rates for the Finnish male population. $(O=$ observed, SMR = standardized mortality ratio, 95 $\% \mathrm{Cl}=95 \%$ confidence interval).

\begin{tabular}{|c|c|c|c|c|c|c|c|c|c|c|c|c|c|c|c|c|c|}
\hline \multirow{4}{*}{$\begin{array}{l}\text { Age } \\
\text { group } \\
\text { (years) }\end{array}$} & \multirow{4}{*}{$\begin{array}{l}\text { Person- } \\
\text { years }\end{array}$} & \multicolumn{16}{|c|}{ Cause of death } \\
\hline & & \multirow{2}{*}{\multicolumn{2}{|c|}{$\begin{array}{c}\text { All } \\
\text { deaths }\end{array}$}} & \multirow{2}{*}{\multicolumn{2}{|c|}{$\begin{array}{l}\text { Violent } \\
\text { deaths }\end{array}$}} & \multirow{2}{*}{\multicolumn{2}{|c|}{$\begin{array}{c}\text { Respiratory } \\
\text { diseases }\end{array}$}} & \multicolumn{4}{|c|}{ Cardiovascular diseases } & \multicolumn{6}{|c|}{ Tumors } \\
\hline & & & & & & & & \multicolumn{2}{|c|}{ All } & \multicolumn{2}{|c|}{$\begin{array}{c}\text { Coronary } \\
\text { heart } \\
\text { disease }\end{array}$} & \multicolumn{2}{|c|}{ All } & \multicolumn{2}{|c|}{$\begin{array}{l}\text { Lung } \\
\text { cancer }\end{array}$} & \multicolumn{2}{|c|}{$\begin{array}{l}\text { Cancer } \\
\text { of the } \\
\text { digestive } \\
\text { organs }\end{array}$} \\
\hline & & 0 & E & 0 & $E$ & $O^{b}$ & $E$ & 0 & $E$ & 0 & $E$ & 0 & E & 0 & $\mathbf{E}$ & 0 & $E$ \\
\hline $\begin{array}{r}15-24 \\
25-34 \\
35-44 \\
45-54 \\
55-64 \\
65-74 \\
\geq 75\end{array}$ & $\begin{array}{r}2108 \\
5188 \\
4748 \\
3985 \\
2848 \\
1150 \\
138\end{array}$ & $\begin{array}{r}4 \\
8 \\
18 \\
31 \\
71 \\
81 \\
22\end{array}$ & $\begin{array}{r}3.2 \\
10.3 \\
22.4 \\
41.5 \\
71.4 \\
62.6 \\
18.3 \\
\end{array}$ & $\begin{array}{l}2 \\
7 \\
5 \\
4 \\
8 \\
2 \\
-\end{array}$ & $\begin{array}{l}2.6 \\
6.8 \\
9.4 \\
8.6 \\
6.4 \\
2.8 \\
0.6\end{array}$ & $\begin{array}{r}- \\
2 \\
1 \\
8 \\
12 \\
5\end{array}$ & $\begin{array}{l}0.1 \\
0.2 \\
0.4 \\
1.8 \\
3.5 \\
5.4 \\
2.5\end{array}$ & $\begin{array}{r}- \\
1 \\
5 \\
13 \\
32 \\
42 \\
7\end{array}$ & $\begin{array}{r}0.1 \\
1.2 \\
8.1 \\
21.0 \\
39.6 \\
34.8 \\
10.7\end{array}$ & $\begin{array}{r}- \\
2 \\
9 \\
22 \\
22 \\
5\end{array}$ & $\begin{array}{r}0.0 \\
0.3 \\
5.4 \\
16.0 \\
28.6 \\
21.4 \\
4.7\end{array}$ & $\begin{array}{r}- \\
2 \\
5 \\
13 \\
18 \\
8\end{array}$ & $\begin{array}{r}0.2 \\
1.0 \\
3.0 \\
6.5 \\
16.8 \\
14.5 \\
2.9\end{array}$ & $\begin{array}{r}- \\
\overline{-} \\
6 \\
11 \\
4\end{array}$ & $\begin{array}{l}0.0 \\
0.0 \\
0.4 \\
2.4 \\
7.8 \\
5.8 \\
0.7\end{array}$ & $\begin{array}{l}- \\
\overline{1} \\
-6 \\
5 \\
3\end{array}$ & $\begin{array}{l}0.0 \\
0.2 \\
0.4 \\
1.5 \\
3.1 \\
3.6 \\
0.9\end{array}$ \\
\hline Total & 20165 & 235 & 229.7 & 28 & 37.2 & 28 & $13.9^{* * *}$ & 100 & 115.5 & 60 & 76.4 & 46 & 44.9 & 22 & 17.1 & 15 & 9.7 \\
\hline $\begin{array}{l}\text { SMR } \\
95 \% \mathrm{Cl}\end{array}$ & . & \multicolumn{2}{|c|}{$\begin{array}{c}102 \\
90-116\end{array}$} & \multicolumn{2}{|c|}{$50-109$} & \multicolumn{2}{|c|}{$\begin{array}{c}201 \\
134-291\end{array}$} & \multicolumn{2}{|c|}{$\begin{array}{c}87 \\
70-105\end{array}$} & \multicolumn{2}{|c|}{$\begin{array}{c}79 \\
60-202\end{array}$} & \multicolumn{2}{|c|}{$\begin{array}{c}102 \\
75-137\end{array}$} & \multicolumn{2}{|c|}{$80-195$} & \multicolumn{2}{|c|}{$\begin{array}{c}155 \\
87-255\end{array}$} \\
\hline
\end{tabular}

a Violent deaths $=I C D$ E $800-E 999$, respiratory diseases $=I C D 460-519$, cardiovascular diseases $=1 C D 390-428$, coronary heart disease $=$ ICD $410-414$, tumors = ICD 140-239, lung cancer = ICD 162, cancer of digestive organs = ICD $150-159$ (ICD = International Classification of Diseases, eighth revision).

- Includes 10 silicotic deaths.

$* * * p<0.001$, Poisson distribution. 
Table 2. Observed $(O)$ and expected $(E)$ numbers of certain causes of death and the standardized mortality ratios (SMR) for the cohort of granite workers at the end of the follow-up. The period of entry was defined as $1950-1971$.

\begin{tabular}{|c|c|c|c|c|c|c|c|c|c|}
\hline \multirow{2}{*}{ Cause of death } & \multicolumn{3}{|c|}{$1940-1972$} & \multicolumn{3}{|c|}{$1940-1975$} & \multicolumn{3}{|c|}{$1940-1981$} \\
\hline & 0 & $E$ & SMR & 0 & $E$ & SMR & 0 & E & SMR \\
\hline All deaths & 119 & 131.2 & 91 & 146 & 154.6 & 94 & 235 & 229.7 & 102 \\
\hline Cardiovascular disease & 46 & $64.4^{*}$ & 71 & 54 & $76.6^{\star \star}$ & 70 & 100 & 115.5 & 87 \\
\hline Tumors & 21 & 24.5 & 86 & 29 & 29.1 & 100 & 46 & 44.9 & 102 \\
\hline Lung cancer & 4 & 9.0 & 44 & 8 & 10.8 & 74 & 22 & 17.1 & 129 \\
\hline Cancer of the digestive organs & $12^{\mathrm{a}}$ & 6.5 & 185 & 15 & $7.4^{\star}$ & 203 & 15 & 9.7 & 155 \\
\hline Respiratory diseases & 11 & $5.5^{\star}$ & 200 & 18 & $6.8^{* * *}$ & 265 & 28 & $13.9^{* * *}$ & 201 \\
\hline Violent deaths & 17 & 19.9 & 85 & 20 & 23.1 & 87 & 28 & 37.2 & 75 \\
\hline
\end{tabular}

${ }^{a} p \approx 0.05,{ }^{*} p<0.05,{ }^{* *} p<0.01,{ }^{* * *} p<0.001$, Poisson distribution.

Table 3. Observed $(\mathrm{O})$ and expected $(E)$ deaths by certain causes of deatil (based on age-specific figures) in the cohort of granite workers according to years since entry into granite work. The period of entry was defined as $1940-1971$ and the period of the follow-up as $1940-1981$.

\begin{tabular}{|c|c|c|c|c|c|c|c|c|c|c|c|c|c|c|}
\hline \multirow{3}{*}{ Cause of death } & \multicolumn{14}{|c|}{ Years since entry into granite work } \\
\hline & \multicolumn{2}{|r|}{0} & \multicolumn{2}{|r|}{5} & \multicolumn{2}{|r|}{10} & \multicolumn{2}{|r|}{15} & \multicolumn{2}{|r|}{20} & \multicolumn{2}{|r|}{25} & \multicolumn{2}{|c|}{30} \\
\hline & 0 & E & 0 & $E$ & 0 & E & 0 & $\mathrm{E}$ & 0 & E & 0 & $\mathrm{E}$ & 0 & $\mathrm{E}$ \\
\hline \multirow{7}{*}{$\begin{array}{l}\text { All deaths } \\
\text { Cardiovascular diseases } \\
\text { Coronary heart disease } \\
\text { Respiratory diseases } \\
\text { Tumors } \\
\text { Lung cancer } \\
\text { Cancer of the digestive } \\
\text { organs }\end{array}$} & 235 & 229.7 & 218 & 201.7 & 191 & $163.3^{*}$ & 153 & $118.1^{\star \star *}$ & 102 & $76.1^{* *}$ & 55 & 43.7 & 29 & 18.5 \\
\hline & 100 & 115.5 & 98 & 103.7 & 88 & 85.9 & 71 & 63.4 & 47 & 41.5 & 24 & 24.1 & 12 & 10.3 \\
\hline & 60 & 76.4 & 59 & 68.3 & 56 & 56.2 & 46 & $41.2 \ldots$ & 29 & 26.6 & 12 & 15.3 & 7 & 6.4 \\
\hline & 28 & $13.9^{* \star *}$ & 27 & $12.8^{* \star \star}$ & 24 & $10.9^{* * \star}$ & 19 & $8.4^{* \star}$ & 13 & $5.8^{*}$ & 7 & 3.5 & 6 & $1.6^{*}$ \\
\hline & 46 & 44.9 & 41 & 40.1 & 38 & 32.9 & 35 & 24.2 & 26 & $15.8^{*}$ & 17 & $9.2^{*}$ & 6 & 4.0 \\
\hline & 22 & 17.1 & 22 & 15.4 & 22 & $12.8^{*}$ & 21 & $9.5^{* *}$ & 15 & $6.3^{\star *}$ & 11 & $3.7^{* *}$ & 3 & 1.6 \\
\hline & 15 & 9.7 & 11 & 8.8 & 9 & 7.4 & 8 & 5.5 & 6 & 3.7 & 2 & 2.2 & - & 1.0 \\
\hline
\end{tabular}

${ }^{*} p<0.05,{ }^{* *} p<0.01,{ }^{* *} p<0.001$, Poisson distribution.

matoid arthritis was mentioned as a secondary cause of death for one person who died of silicosis. Silicosis was mentioned as a secondary cause in the three cases of cardiovascular death (in one of them lung tuberculosis was mentioned as an additional secondary cause), in one case of chronic pyelonephritis together with silicosis, and in one case of lung tuberculosis. In all, lung tuberculosis was observed in five cases as the main cause and in two cases as a secondary cause of death. In addition to being reported as a secondary cause in the case of two silicotic deaths, lung tuberculosis was also mentioned in connection with different cardiovascular deaths. Rheumatoid arthritis was reported as an additional secondary cause of death in one case of lung tuberculosis.

Diseases of the urinary tract were observed as the main cause of death in four cases (expected 1.8), three of which were chronic pyelonephritis (expected 0.6), and the other was chronic nephritis. As other than the primary cause of death, renal disease was reported in five cases. Three cases of urinary tract disease were associated with rheumatoid arthritis on the death certificates.

Rheumatoid arthritis was reported on nine death certificates (on two of them as the primary cause). In addition, one case of polyarteritis nodosa-like rheumatoid arthritis was observed.

Comparison of the results for mortality until the end of the three follow-up periods revealed variations in the cause-specific results. The first follow-up through
1972 (table 2) indicated a slightly higher mortality from respiratory diseases and cancer of the digestive organs than expected on the basis of national rates. The second follow-up in 1975 confirmed an excess mortality from both types of disease. Mortality from cardiovascular diseases was clearly lower than expected. The third follow-up through 1981 revealed increasing mortality from lung cancer. Mortality from respiratory and cardiovascular diseases was similar during the first and second follow-up periods.

The analysis of mortality according to years since entry into granite work (latency) revealed excess mortality from tumors in the group of workers followed for 20 years or more (observed 26, expected 15.8, $\mathrm{p}<0.05$ ). The greatest excess was found between 25 to 29 years after the commencement of exposure. The excess was mainly caused by lung cancer (observed 8 , expected 2.1) (table 3). The analysis of the other causes of death according to the length of follow-up did not show any specific time dependency.

\section{Disability}

The disability of granite workers was studied twice, until the end of 1971 and the end of 1981. At the end of the first follow-up in 1971 the total number of disability pensions for granite workers ( 39 observed) was statistically significantly higher than that for the Finnish male population $(27.8$ expected, $\mathrm{p}<0.05)$. The 
Incidence densityl

1000 person-years

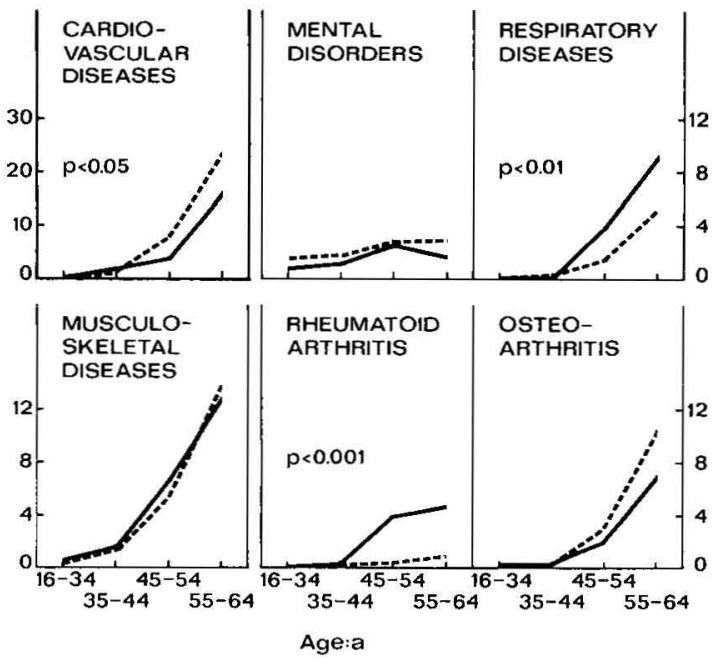

Figure 2. Incidence densities of new disability pensions among granite workers during 1969-1981. (- granite workers,.- active male population, $a=$ years) primary causes of the excess were musculoskeletal diseases (13 observed versus 3.8 expected, $p<0.001$ ), mainly osteoarthritis and rheumatoid arthritis. Disability due to tuberculosis of the lungs was also more frequent than expected ( 5 observed versus 0.9 expected, $\mathrm{p}<0.05$ ).

In the second follow-up new disability pensions during 1969 to the end of 1981 were studied (figure 2). A comparison of the granite workers and the Finnish male population of working capacity did not reveal any essential differences with respect to the incidence rates for all disability pensions. However, a comparison of the cause-specific results showed significantly higher incidences of respiratory disease and rheumatoid arthritis among the granite workers. The incidence results were verified through the calculation of the prevalent numbers of disability at the end of 1981 (table 4). According to these calculations mental disorders were less frequent among granite workers than expected. Respiratory diseases were more frequent than expected $(9$ observed versus 4.4 expected). The excess was mainly caused by silicosis and chronic bronchitis. Excessive numbers were also found for rheumatoid arthritis (10 observed versus 1.8 expected).

Table 4. Observed $(\mathrm{O})$ and expected $(\mathrm{E})$ numbers of certain causes of disability among the granite workers on 31 December 1981 according to the age group of the workers. The expected numbers are calculated on the basis of age-specific proportional disability rates for the Finnish male population from the same date.

\begin{tabular}{|c|c|c|c|c|c|c|c|c|c|c|c|c|c|c|c|}
\hline \multirow{4}{*}{$\begin{array}{l}\text { Age } \\
\text { group } \\
\text { (years) }\end{array}$} & \multicolumn{15}{|c|}{ Cause of disability } \\
\hline & \multirow{3}{*}{$\begin{array}{l}\text { All } \\
\text { causes } \\
\text { (0) }\end{array}$} & & & & & \multicolumn{6}{|c|}{ Musculoskeletal diseases } & \multicolumn{4}{|c|}{ Cardiovascular diseases } \\
\hline & & \multicolumn{2}{|c|}{$\begin{array}{c}\text { Mental } \\
\text { disorders }\end{array}$} & \multicolumn{2}{|c|}{$\begin{array}{l}\text { Respiratory } \\
\text { diseases }\end{array}$} & \multicolumn{2}{|c|}{ All } & \multicolumn{2}{|c|}{$\begin{array}{l}\text { Rheumatoid } \\
\text { arthritis }\end{array}$} & \multicolumn{2}{|c|}{$\begin{array}{l}\text { Osteo- } \\
\text { arthritis }\end{array}$} & \multicolumn{2}{|c|}{ All } & \multicolumn{2}{|c|}{$\begin{array}{l}\text { Coronary } \\
\text { heart } \\
\text { disease }\end{array}$} \\
\hline & & 0 & $\mathrm{E}$ & o & E & $\mathrm{o}$ & E & 0 & $E$ & 0 & $E$ & 0 & $E$ & 0 & $E$ \\
\hline $\begin{array}{l}16-34 \\
35-39 \\
40-44 \\
45-49 \\
50-54 \\
55-59 \\
60-64\end{array}$ & $\begin{array}{r}3 \\
-2 \\
8 \\
14 \\
25 \\
24\end{array}$ & $\begin{array}{l}\frac{2}{2} \\
\frac{2}{5} \\
1 \\
2\end{array}$ & $\begin{array}{l}2.2 \\
0.0 \\
1.1 \\
3.0 \\
3.6 \\
4.0 \\
2.6\end{array}$ & $\begin{array}{l}- \\
z \\
1 \\
1 \\
4 \\
3\end{array}$ & $\begin{array}{l}0.0 \\
0.0 \\
0.0 \\
0.3 \\
0.6 \\
1.6 \\
1.9\end{array}$ & $\begin{array}{r}1 \\
- \\
1 \\
4 \\
8 \\
10\end{array}$ & $\begin{array}{l}0.1 \\
0.0 \\
0.2 \\
1.4 \\
3.1 \\
6.5 \\
6.7\end{array}$ & $\begin{array}{l}- \\
\bar{z} \\
\overline{3} \\
5 \\
2\end{array}$ & $\begin{array}{l}0.0 \\
0.0 \\
0.1 \\
0.2 \\
0.4 \\
0.6 \\
0.5\end{array}$ & $\begin{array}{l}z \\
\bar{z} \\
\overline{1} \\
1 \\
7\end{array}$ & $\begin{array}{l}0.0 \\
0.0 \\
0.0 \\
0.5 \\
1.5 \\
4.0 \\
4.8\end{array}$ & $\begin{array}{l}- \\
\overline{-} \\
\overline{2} \\
3 \\
3 \\
7\end{array}$ & $\begin{array}{l}0.0 \\
0.0 \\
0.2 \\
1.3 \\
3.5 \\
7.8 \\
8.4\end{array}$ & $\begin{array}{l}- \\
z \\
\overline{1} \\
1 \\
1 \\
5\end{array}$ & $\begin{array}{l}0.0 \\
0.0 \\
0.1 \\
0.7 \\
2.2 \\
4.8 \\
4.9\end{array}$ \\
\hline Total & 76 & 12 & 16.5 & 9 & 4.4 & 24 & 18.0 & 10 & $1.8^{* *}$ & 8 & 10.8 & 15 & 21.2 & 7 & 12.7 \\
\hline
\end{tabular}

*. $p<0.01$, Poisson distribution.

Table 5. Observed $(O)$ and expected $(E)$ numbers of granite workers receiving free medication on 31 December 1981 according to the age group of the workers and the type of disease for which the medication was granted. The expected numbers were calculated on the basis of national age-specific proportional rates from the same date.

\begin{tabular}{|c|c|c|c|c|c|c|c|c|c|c|c|c|c|c|c|c|c|}
\hline \multirow{3}{*}{$\begin{array}{l}\text { Age } \\
\text { group } \\
\text { (years) }\end{array}$} & \multicolumn{17}{|c|}{ Type of disease } \\
\hline & \multirow[t]{2}{*}{$\begin{array}{c}\text { All } \\
\text { diseases } \\
\text { (O) }\end{array}$} & \multicolumn{2}{|c|}{ Diabetes } & \multicolumn{2}{|c|}{$\begin{array}{l}\text { Schizo- } \\
\text { phrenia }\end{array}$} & \multicolumn{2}{|c|}{$\begin{array}{l}\text { Congestive } \\
\text { heart } \\
\text { failure }\end{array}$} & \multicolumn{2}{|c|}{$\begin{array}{l}\text { Rheumatoid } \\
\text { arthritis }\end{array}$} & \multicolumn{2}{|c|}{$\begin{array}{l}\text { Bronchial } \\
\text { asthma }\end{array}$} & \multicolumn{2}{|c|}{$\begin{array}{c}\text { Chronic } \\
\text { pyelo- } \\
\text { nephritis }\end{array}$} & \multicolumn{2}{|c|}{$\begin{array}{l}\text { Hyper- } \\
\text { tension }\end{array}$} & \multicolumn{2}{|c|}{ Others } \\
\hline & & 0 & $E$ & 0 & $\mathrm{E}$ & 0 & $E$ & 0 & $E$ & 0 & $E$ & 0 & $E$ & 0 & $E$ & 0 & $E$ \\
\hline $\begin{array}{r}15-34 \\
35-39 \\
40-44 \\
45-49 \\
50-54 \\
55-59 \\
60-64 \\
65-69 \\
\geq 70\end{array}$ & $\begin{array}{r}9 \\
12 \\
10 \\
20 \\
27 \\
32 \\
19 \\
29 \\
31\end{array}$ & $\begin{array}{r}1 \\
1 \\
2 \\
4 \\
4 \\
2 \\
2\end{array}$ & $\begin{array}{l}1.4 \\
1.2 \\
0.8 \\
1.6 \\
2.2 \\
2.8 \\
1.8 \\
2.7 \\
3.3\end{array}$ & $\begin{array}{l}3 \\
2 \\
3 \\
1 \\
2 \\
- \\
1 \\
-\end{array}$ & $\begin{array}{l}1.4 \\
2.0 \\
1.2 \\
1.6 \\
1.4 \\
1.0 \\
0.4 \\
0.3 \\
0.1\end{array}$ & $\begin{array}{l}- \\
- \\
- \\
- \\
2 \\
5 \\
3 \\
7 \\
13\end{array}$ & $\begin{array}{r}0.1 \\
0.2 \\
0.3 \\
1.2 \\
3.1 \\
5.7 \\
4.3 \\
8.5 \\
11.6\end{array}$ & $\begin{array}{l}- \\
-2 \\
1 \\
2 \\
5 \\
3 \\
2 \\
2\end{array}$ & $\begin{array}{l}0.5 \\
0.8 \\
0.6 \\
1.1 \\
1.2 \\
1.3 \\
0.7 \\
1.0 \\
0.9\end{array}$ & $\begin{array}{l}2 \\
3 \\
3 \\
2 \\
2 \\
2 \\
4 \\
-\end{array}$ & $\begin{array}{l}1.4 \\
0.9 \\
0.7 \\
1.2 \\
1.5 \\
1.7 \\
0.9 \\
1.2 \\
0.8\end{array}$ & $\begin{array}{l}-1 \\
- \\
- \\
-1 \\
- \\
-\end{array}$ & $\begin{array}{l}0.1 \\
0.1 \\
0.1 \\
0.1 \\
0.1 \\
0.2 \\
0.1 \\
0.3 \\
0.8\end{array}$ & $\begin{array}{r}1 \\
6 \\
2 \\
9 \\
14 \\
11 \\
7 \\
7 \\
9\end{array}$ & \begin{tabular}{r|}
1.1 \\
4.2 \\
4.4 \\
10.2 \\
13.9 \\
15.4 \\
8.4 \\
8.4 \\
11.1 \\
8.6
\end{tabular} & $\begin{array}{l}2 \\
1 \\
4 \\
1 \\
4 \\
2 \\
6 \\
5\end{array}$ & $\begin{array}{l}3.0 \\
2.7 \\
1.8 \\
3.0 \\
3.5 \\
3.9 \\
2.3 \\
3.7 \\
5.0\end{array}$ \\
\hline Total & 189 & 16 & 17.7 & 12 & 9.4 & 30 & 35.0 & 19 & $8.1^{* * *}$ & 19 & $10.3^{*}$ & 2 & 1.9 & 66 & 77.3 & 25 & 28.9 \\
\hline
\end{tabular}

$* p<0.05, \cdots p<0.001$, Poisson distribution. 


\section{Granting of free medication}

Chronic diseases were also measured by the occurrence of diseases for which free medication was granted by the national sickness insurance. The numbers of persons with free medication at the end of the first followup were few, a slight excess being observed for rheumatoid arthritis and bronchial asthma (1). The prevalence rates for free medication at the end of the second follow-up in 1981 are presented in table 5. At this time both rheumatoid arthritis (19 observed versus 8.1 expected cases) and bronchial asthma (19 observed versus 10.3 expected cases) were more common as causes of free medication among the granite workers than among the general male population.

The granting of free medication for congestive heart failure and hypertension was less frequent than expected among the granite workers. This finding was compatible with the mortality and disability results. The other disease groups did not show any essential differences between the granite workers and the general male population of the same age.

\section{Discussion}

\section{Variations in the time-specific rates}

Our mortality study of granite workers has given different results for the three periods of follow-up (19401972, 1940-1975, and 1940 - 1981) (table 2). The results for the mortality of even the same cohort depend on whether they are calculated as period-specific or cumulative or according to years since entry. The detection of potential excessive mortality from a certain disease, particularly from cancer, requires the recognition of the optimum composition of the periods of entry, the periods of follow-up, and the age structure of the cohort (18). The internal structure of our granite cohort showed that excess overall mortality did not become evident until the granite workers had been followed for at least 20 years, but still in 1981 only $15 \%$ of the granite workers could be followed for this length of time.

A comparison of the mortality results of different cohorts is even more difficult. Inconsistencies in the earlier reported results can be explained by differences in (i) study design, (ii) the internal structure of the cohort [period of entry, period of follow-up, age structure, and occurrence of disease (eg, tumors) in the population], (iii) potential confounders and methods of analysis, and (iv) differences in exposure intensity and duration $(18,19)$.

\section{Violent deaths}

The low mortality from violent deaths probably reflects physical and mental health selection before employment, and it was probably also influenced by workers remaining in that occupation. The minimum require- ment of three months of employment before entry into the granite work cohort studied by us may also explain these low rates.

\section{Cardiovascular deaths}

The low mortality (in comparison with the expected values) from cardiovascular diseases, and also from coronary heart disease separately, particularly during follow-up periods of less than 15 years, can be explained by the selection of healthy workers for granite work. The healthy worker effect was further demonstrated by the low morbidity rates (incidence and prevalence of disability and free medication for hypertension and cardiac insufficiency). In spite of the low mortality and morbidity rates in the short follow-up periods, the mortality rates indicated an excess of cardiovascular diseases among the older workers after more than 15 years of follow-up.

\section{Cancer}

Epidemiologic studies have suggested an excess risk for cancer among workers exposed simultaneously to quartz dust and confounding carcinogens (radon, asbestos, polycyclic aromatic hydrocarbons, some metals) $(4,10,15,16,24,34)$. On the contrary, the few studies available on workers exposed to "pure" silica indicate only slight or no excess mortality from cancer $(8,33)$. This diversity has been seen both in exposure cohorts and in cohorts of silicotic patients, as well as in case-referent studies $(9,11,12,14,29,35,40)$.

The present study showed that the overall mortality from tumors for the whole period of follow-up (1940 to 1981) was similar to that expected. However, a stratified analysis revealed a significant excess in mortality after a minimum latency of 15 years, with a maximum excess during the follow-up period of $25-29$ years. The excess was entirely caused by cancer of the lungs and cancer of the gastrointestinal tract (mainly stomach cancer).

Our granite workers were exposed to pure silica unconfounded by other occupational and nonoccupational carcinogens. In addition the periods of exposure and follow-up were long. Among workers deceased due to lung cancer, there was only one case of manifest pulmonary silicosis. Furthermore an excess mortality from gastrointestinal cancer was observed. Taken together, these facts would suggest that silica exposure per se influences the development of lung cancer. This conclusion is not contradictory to earlier proposed connections between lung cancer and silicosis. The association between silica exposure and cancer has been discussed in detail in a separate paper (19).

\section{Musculoskeletal diseases}

Excessive morbidity from rheumatoid arthritis was observed in the prevalence numbers for disability and free 
medication in both 1971 and 1981. The excess in 1981 was not caused only by the cases of 1971 , because the incidence rates of rheumatoid arthritis for the period between 1969 to 1981 were also significantly higher than the expected national values. On the contrary, although the prevalent number of cases of osteoarthritis was excessive in 1971, new cases during 1969-1981 were fewer than expected, with a consequent decrease in the prevalent number in 1981. The disappearance of osteoarthritis as a cause of morbidity among granite workers may depend on changes in the physical demands and work loads due to technical development of the work process.

An epidemiologic study of miners and ex-miners in a defined population showed no increase in the prevalence of rheumatoid arthritis (23). The author concluded that exposure to dust was of no etiologic importance for the disease. However, there are studies that have demonstrated an association between silica exposure and connective tissue diseases, eg, rheumatoid arthritis (5), systemic lupus erythematosus (6), and progressive systemic sclerosis (30). In fact the concept of silicoarthritis has appeared in the literature (22). In the present study no case of Caplan's syndrome (rheumatoid pneumoconiosis) was found.

The etiopathogenetic events behind the association between silica exposure and rheumatoid arthritis are not known. Hypothetically, exposure to dust may modify the host's defense against the unknown exogenous agent that causes rheumatoid arthritis or decrease resistance to other etiologic factors starting an immunologic arthritic process. Still, the initiation and perpetuation of the inflammatory joint disease may be influenced by the high prevalence of autoantibodies (rheumatic factor, antinuclear antibodies, etc) observed among silica exposed workers and by the silicamediated cytotoxicity of macrophages (2). The association between exposure to granite dust and rheumatoid arthritis has been discussed in another report that is as yet unpublished.

\section{Respiratory diseases}

The association between prolonged silica exposure and lung disease, eg, pneumoconiosis, silicotuberculosis, emphysema, and heart disease caused by pulmonary hypertension, is well recognized. Excess mortality and disability from respiratory diseases was obvious in all the follow-up studies of the present cohort. The excess rates became the most evident 10 years after the first exposure to granite dust.

Inhalation of granite dust has not been clearly established as a cause of chronic obstructive bronchitis (27). The excess number of workers granted free medication due to bronchial asthma can be explained in several ways. It is likely that males with even a slight predisposition to bronchial hyperreactivity would develop symptoms of bronchial obstruction even under nonspecific environmental exposure to dust. The ex- cess number granted free medication for bronchial asthma may also be explained by diagnostic difficulties and by the fact that free medication is not granted for chronic bronchitis.

\section{Other diseases}

Although the number of persons receiving free medication for diabetes did not differ from that of the reference population, diabetes was mentioned on exceptionally many death certificates as a secondary cause of death, and also on sickness insurance records. This association is a subject for further case-oriented studies. In addition, a number of other probable or possible disease associations were identified, ie, glomerulonephritis, amyloidosis and mesenchymal malignancies (chronic lymphocytic leukemia, lymphosarcoma, osteosarcoma, polycythemia vera). However, the small number of cases hinders any definite conclusions about a possible association with exposure to granite dust.

\section{Acknowledgments}

We thank Ms R Vuorela for collecting the data from the employers' records, and R Luukkonen, MSc, for assisting with the data processing. We express our sincerest thanks to A-M Bolander, MD hc, Swedish Statistics, for her assistance in tracing those of the cohort who had emigrated to Sweden and for gathering death certificates in Sweden.

We also thank the Social Insurance Institution for the disability and free-medication data, and the Central Statistical Office of Finland for the data on causes of deaths.

\section{References}

1. Ahlman K, Backman A-L, Hannunkari I, Järvinen E, Koponen E, Koskela R-S, Partanen T, Seppäläinen AM, Starck J. Kivityöntekijöiden työolosuhteet ja terveydentila [Work conditions and health of granite workers]. Social Insurance Institution, Helsinki 1975. (Kansaneläkelaitoksen julkaisuja AL: 4/1975). (English summary).

2. Allison AC, Harrington J, Birbeck M. An examination of the cytotoxic effects of silica on macrophages. J Exp Med 124 (1966) 141-154.

3. Asp S. Confounding by variable smoking habits in different occupational groups. Scand J Work Environ Health 10 (1984) 325-326.

4. Axelson O, Sundell L. Mining, lung cancer and smoking. Scand J Work Environ Health 4 (1978) 46-52.

5. Benedek T. Rheumatoid pneumoconiosis: Documentation of onset and pathogenic considerations. Am J Med 55 (1973) 515-524.

6. Bernardini P, Iannoconi A. Pulmonary silicosis associated with systemic lupus erythematosus. Lav Um 30 (1982) $799-802$.

7. Caplan A. Certain radiological appearances in the chest of coal miners suffering from rheumatoid arthritis. Thorax 8 (1953) 29-37.

8. Davis LK, Wegman DH, Monson RR, Froines J. Mortality experience of Vermont granite workers. Am J Ind 
Med 4 (1983) 705-723.

9. Finkelstein M, Kusiak R, Suranyi G. Mortality among miners receiving workmen's compensation for silicosis in Ontario: 1940-1975. J Occup Med 24 (1982) 663667.

10. Fox AJ, Goldblatt A, Kinlen LJ. A study of the mortality of Cornish tin miners. Br J Ind Med 38 (1981) $378-380$.

11. Goldsmith DF, Guidotti TL, Johnston DR. Does occupational exposure to silica cause lung cancer? Am J Ind Med 3 (1982) 423-440.

12. Gudbergsson H, Kurppa K, Koskinen H, Vasama M. An association between silicosis and lung cancer: A register approach. In: Bergbau-Berufsgenossenschaft. Proceedings of the VI International Pneumoconiosis Conference, Bochum, FRG, September 20-23, 1983. Volume 1. Bochum 1984, pp 212-216.

13. Hauglustaine D, Van Damme B, Deanens P, Michielsen P. Silicon nephropathy: A possible occupational hazard. Nephron 26 (1980) 219-224.

14. Hessel PA, Sluis-Cremer GK. Case-control study of lung cancer and silicosis. In: Goldsmith DF, Winn DM, Shy $\mathrm{CM}$, ed. Silica, silicosis and cancer: Controversy in occupational medicine. Praeger Publishers, New York, NY 1986, pp 351-355. (Cancer research monographs, volume 2).

15. Katsnelson BA, Mokronosova KA. Non-fibrous mineral dusts and malignant tumors. J Occup Med 21 (1979) $15-20$.

16. Koskela R-S, Hernberg S, Kärävä R, Järvinen E, Nurminen M. A mortality study of foundry workers. Scand J Work Environ Health 2 (1976): suppl 1, 73-89.

17. Koskela R-S, Järvinen E. Kivityöntekijöiden kuolleisuus, työkyvyttömyys, sairastavuus sekä työntekijöiden mielipiteet kivityöhön liittyvistä terveydellisistä ongelmista. [Mortality, disability and health among granite workers] In: Ahlman K, Backman AL, Hannunkari I, Järvinen E, Koponen M, Koskela R-S, Partanen T, Seppäläinen AM, Starck J. Kivityöntekijöiden työolosuhteet ja terveydentila [Work conditions and health of granite workers]. Social Insurance Institution, Helsinki 1975, pp 89-117. (Kansaneläkelaitoksen julkaisuja AL 4/1975).

18. Koskela R-S, Järvinen E, Kolari PJ. Effect of cohort definition and follow-up length on occupational mortality rates. Scand J Work Environ Health 10 (1984) $311-316$.

19. Koskela R-S, Klockars M, Järvinen E, Kolari PJ, Rossi A. Cancer mortality of granite workers. Scand J Work Environ Health 13 (1987) 26-31.

20. Kurppa K, Koskela R-S, Gudbergsson H. Gastrointestinal cancer in workers exposed to quartz. Lancet 1 (1982) 150.

21. Lentner C, ed. Geigy scientific tables. Volume 2. Eighth edition. Ciba-Geigy Limited, Basel 1982.

22. Makarenko II. Some non-specific syndromes in silicosis [in Russian]. Sov med 26 (1963) 35-41.

23. Miall WE. Rheumatoid arthritis in males: An epidemiological study of a Welsh mining community. Ann Rheum Dis 14 (1955) $150-158$.

24. Milham S Jr. Occupational mortality in Washington State, 1950-1971. US Government Printing Office,
Washington, DC 1976. DHEW (NIOSH) publication no 76-175-A).

25. Mustonen R. Suomalaisten rakennusmateriaalien luonnollinen radioaktiivisuus [Natural radioactivity of Finnish building materials]. Finnish Institute of Radiation Protection, Helsinki 1978. (Säteilyturvakeskuksen raporttisarja STL-B10).

26. National Board of Health. Tauti- ja kuolinsyyluokitus [WHO. The international statistical classification of diseases, injuries and causes of death]. Helsinki 1969.

27. Parkes WR. Occupational lung disorders. Second Edition. Butterworths, London 1982.

28. Rothman KJ, Boice JD Jr. Epidemiologic analysis with a programmable calculator. Epidemiology Resources, Inc, Boston, MA 1982.

29. Schüler G, Rüttner J. Silicosis and lung cancer in Switzerland, In: Goldsmith DF, Winn DM, Shy CM, ed. Silica, silicosis and lung cancer: Controversy in occupational medicine. Praeger Publishers, New York, NY 1986, pp 357-366. (Cancer research monographs, volume 2).

30. Sluis-Cremer GK, Hessel PA, Nizdo EH, Churhill AR, Zeiss EA. Silica, silicosis and progressive systemic sclerosis. Br J Ind Med 42 (1985) 838-843.

31. Social Insurance Institution. Kansaneläkelaitoksen tilastollisia vuosikatsauksia 1981 [Statistical review of the Social Insurance Institution, 1981]. Helsinki 1982. (Kansaneläkelaitoksen julkaisuja T3:10C).

32. Social Insurance Institution. Kokonaan korvattaviin lääkkeisiin oikeuttavat sairaudet 31. 12. 1981 [Statistics on diseases conferring entitlement to free medicines under national sickness insurance, 31 December 1981]. Helsinki 1985. (Kansaneläkelaitoksen julkaisuja T6:16).

33. Steenland K, Beaumont J. A proportionate mortality study of granite cutters. Am J Ind Med 9 (1986) 189201.

34. Tola S, Koskela R-S, Hernberg S, Järvinen E. Lung cancer mortality among iron foundry workers. J Occup Med 21 (1979) 753-760.

35. Westerholm P. Silicosis: Observations on a case register. Scand J Work Environ Health 6 (1980): suppl 2, 1-86.

36. Westerholm P, Ahlmark A, Massing R, Segelberg I. Silicosis and lung cancer - A cohort study. In: Goldsmith DF, Winn DM, Shy CM, ed. Silica, silicosis and cancer: Controversy in occupational medicine. Praeger Publishers, New York, NY 1986, pp 327-333. (Cancer research monographs, volume 2).

37. World Health Organization. World health statistics annual 1965: Vital statistics and causes of death. Geneva 1968.

38. World Health Organization. World health statistics annual 1969: Vital statistics and causes of death. Geneva 1972.

39. World Health Organization. World health statistics annual 1972: Vital statistics and causes of death. Geneva 1975.

40. Zambon P, Pastrangelo G, Saia B. Exposure to silica and lung cancer, a case-control study. Presented at the Montreal Conference on Occupational Health, 23-25 August 1983.

Received for publication: 19 June 1986 